\title{
Perceived discrimination in education and employment by people with Crohn's disease: a case control study of educational achievement and employment
}

\author{
M K Mayberry, C Probert, E Srivastava, J Rhodes, J F Mayberry
}

\begin{abstract}
Eighty three patients in whom the diagnosis of Crohn's disease had been made before the age of 40 years and who had been resident in the city of Cardiff were asked to complete a detailed questionnaire about their educational and employment experiences. Responses were obtained from 58 patients (response rate= $70 \%$ ), 23 buddy controls, and 27 community controls. The mean (SD) age of patients at the time of the survey was 31 (5) years. Twenty four of the patients were diagnosed before leaving secondary education, at a mean age of 17 years. They had lost significantly more days' schooling than controls $\left(\chi^{2}=14 \cdot 3\right.$ $\mathbf{p}<0.001)$ but had achieved similar academic success as measured by examination passes and attendance at tertiary institutes of education. Similar numbers of patients and controls were employed at the time of the survey, although significantly more patients had experienced long term unemployment $(z=2.6 p<0.01)$. As a result of their experiences up to $30 \%$ actively concealed their illness from employers.
\end{abstract}

Crohn's disease is a life long condition which can begin at any age, but often starts during the teens or early 20 s when people are trying to complete their education or first entering regular employment. Although the social toll of Crohn's disease on family life and work has been reviewed in several series, ${ }^{1-4}$ to date there have been no casecontrol studies investigating its possible effects on educational achievement or employment prospects. This knowledge is important as it can provide a sound basis for counselling patients and may lead to a better understanding on the part of teachers, lecturers, and employers.

Gastrointestinal Research Unit, Leicester General Hospital,

Leicester

M K Mayberry

C Probert

J F Mayberry

University Hospital of

Wales, Cardiff

E Srivastava

J Rhodes

Correspondence to:

Ms M K Mayberry,

Gastrointestinal Research

Unit, Leicester General

Hospital, Gwendolen Road,

Leicester LE5 4PW.

Accepted for publication

2 July 1991

\section{Method}

Eighty three patients in whom the diagnosis of Crohn's disease had been made before the age of 40 years were identified from the Cardiff epidemiological data base. ${ }^{5}$ All had been resident in the city at the time of diagnosis and their ages at diagnosis were known. Each patient was asked to provide details of his or her educational and work experiences before and after diagnosis. Information was collected by structured postal questionnaire, which consisted of two sections. In the first section data were collected on age at leaving secondary education and level of academic attaintment. Academic achievement in various secondary school examinations, including certificates of secondary (CSE) and general education (GCE) at ordinary and advanced level, was noted. Time lost from school was also recorded. The number of patients who attended full time further education was noted, together with the type of institution attended for example, university, polytechnic, college of further education, and teacher training institutes. Academic successes including initial and higher degrees as well as professional qualifications were recorded. Patients who developed the disease before finishing their education were asked about their subjective experiences. The attitudes of teachers and lecturers to their illness, its effects on their education, and views on the need for special provisions for children with the disease were sought.

The second section of the questionnaire dealt with work experience and recorded details of current employment and episodes of dismissal and long term unemployment. The type of job was not studied in detail. Again opinions of patients were sought on the need for employers to know of their disease and its possible effect on promotion prospects.

Two control groups were identified and asked to provide comparable answers on the objective parts of the questionnaire - namely age at completion of secondary education, attendance at institutions of higher education, academic qualifications, time lost from school, current employment status, episodes of dismissal, and long term unemployment (periods greater than six weeks). The first control subjects were identified by patients themselves. Each patient was asked to nominate a friend or 'buddy' who would complete the questionnaire, and in about half the cases this was done. A second group of community controls was identified for the remaining patients with the help of the patient's general practitioner. From the practitioner's age and sex register of patients a control of the same age, sex, and area of residence as the patient with Crohn's disease was selected for patients without a 'buddy' control. Questionnaires to both 'buddy' and community controls were distributed by post.

Analysis was by means of $\chi^{2}$ and Student's $t$ test. Buddy and community controls were compared and subsequently patients and control groups.

\section{Results}

Of the 83 patients identified from the Cardiff 
data base, replies were obtained from 58 (response rate $=70 \%$ ). Patients were asked to identify friends or 'buddies' to act as controls and replies were obtained from 23 such people. For the remaining 35 patients, family doctors were asked to identify community controls for named patients and replies were obtained from 27 such people. Although drawn from such different sources there were no statistical differences between these two control groups with the exception of current employment status $(z=2 \cdot 0$, $\mathrm{p}<0.05$; Fleiss, 1981. $)^{6}$ This may reflect biased selection by patients of people with more time to complete questionnaires.

The mean (SD) age of patients at the time of the survey was 31.5 (5) years and their mean age at diagnosis was 20 (5) years. They had left school on average at 17 years old (Table I) compared with 16.9 years for community controls and 16.6 years for buddy controls. In other words, 34 patients were not diagnosed until after they had completed their secondary education. However, $42 \%$ of patients diagnosed while at school had lost at least two weeks schooling because of admission to hospital for their Crohn's disease. This was a significantly greater number than the $4 \%^{7}$ controls who had required hospitalisation for a similar period $\left(\chi^{2}=\right.$ $14.3 \mathrm{p}<0.001)$. However, the time lost by patients because of all forms of illness, including those that did not require hospitalisation was mean (SD) $1 \cdot 8$ (5) (range 0-24) weeks compared with $4.6(1.6)$ (range $0-20)$ weeks by controls $(\mathrm{t}=-2 \cdot 7 ; \mathrm{p}<0.01)$.

Altogether $47 \%$ of patients and $42 \%$ of controls attended full time further education $(z=1 \cdot 2 \mathrm{NS})$. The type of tertiary education was also similar $\left(\chi_{4}^{2}=4.4 \mathrm{NS}\right)$ as were the formal qualifications obtained during both secondary and tertiary education $\left(\chi_{7}^{2}=3 \cdot 3 ; \mathrm{NS}\right)$ (Table I).

Of the 58 patients, 24 were diagnosed before they completed secondary or tertiary education. Some $21 \%$ of these patients found lecturers or teachers indifferent to their illness and $8 \%$ found them hostile. (Table II). Despite their academic success, $17 \%$ of patients had been unable to sit examinations because of illness and $14 \%$ felt that disease had prevented them obtaining the education they would have liked (Table II).

Similar numbers of patients and controls were

TABLE I Educational achievement in young people with Crohn's disease

\begin{tabular}{|c|c|c|c|c|}
\hline & \multirow[b]{2}{*}{$\begin{array}{l}\text { Patients } \\
(n=58)\end{array}$} & \multicolumn{3}{|c|}{ Controls $(n=49)$} \\
\hline & & $\begin{array}{l}\text { Total } \\
(n=50)\end{array}$ & $\begin{array}{l}\text { Buddies } \\
(\mathrm{n}=23)\end{array}$ & $\begin{array}{l}\text { Community } \\
(\mathbf{n}=27)\end{array}$ \\
\hline School leaving age (mean (SD) (yrs)) & $16 \cdot 9(1 \cdot 2)$ & & $16 \cdot 6(1 \cdot 1)$ & $17(2 \cdot 1)$ \\
\hline Hospitalised $>2$ weeks & 10 & 2 & & \\
\hline Mean (SD) period lost from school (wks) & $1 \cdot 8(5)$ & & $3 \cdot 4(5)$ & $5 \cdot 8(6)$ \\
\hline Received full time further education & 27 & 21 & & \\
\hline \multicolumn{5}{|l|}{ Type of further education: } \\
\hline University & 7 & 9 & 3 & 6 \\
\hline Polytechnic & 7 & 1 & 0 & 1 \\
\hline College of further education & 11 & 8 & 2 & 6 \\
\hline Teacher training institute & 3 & 3 & 2 & 1 \\
\hline Other & 3 & 2 & 1 & 1 \\
\hline \multicolumn{5}{|l|}{ Further qualifications } \\
\hline CSE & 29 & 23 & 11 & 12 \\
\hline GCE & 36 & 34 & 13 & 21 \\
\hline GCSE & 1 & 2 & 2 & 0 \\
\hline 'A' levels & 14 & 17 & 6 & 11 \\
\hline HND/HNC & 6 & 4 & 2 & 2 \\
\hline Initial degree & 9 & 12 & 5 & 7 \\
\hline Higher degree & 2 & 3 & 2 & 1 \\
\hline Professional qualifications & 11 & 16 & 6 & 10 \\
\hline
\end{tabular}

TABLE II Views of patients with Crohn's disease on education

\begin{tabular}{ll}
\hline & $\begin{array}{c}\% \text { Patients } \\
(n=24)\end{array}$ \\
\hline $\begin{array}{l}\text { Attitudes of teachers/lecturers: } \\
\text { Aware of the nature of Crohn's disease }\end{array}$ & 33 \\
Attitude to illness: & \\
Sympathetic & 17 \\
Indifferent & 21 \\
Hostile & 8 \\
Special provisions made at time of exams & 8 \\
Views of patients: & $(n=58)$ \\
Unable to sit exams because of illness & 17 \\
Disease prevented education they would have liked & 14 \\
Need for special schools for children with Crohn's & 12 \\
$\quad$ disease & 12 \\
\hline
\end{tabular}

* The attitudes of different teachers and lecturers at different times were reported by individual patients.

employed at the time of the surgery $(z=1 \cdot 3 ; \mathrm{NS})$, although significantly more patients $(50 \%)$ than controls (24\%) had experienced periods of long term unemployment exceeding six weeks because of difficulties in obtaining work $(z=2 \cdot 6$; $\mathrm{p}<0.01$ Table III). Crohn's disease had not led to a greater dismissal rate among patients on either health or other grounds. Despite this, of the 46 patients in employment, $37 \%$ felt that their employers should not know their diagnosis and indeed $30 \%$ were in favour of active concealment of their disease (Table IV). As with education up to $24 \%$ of patients felt their disease had limited their employment prospects and had either prevented them seeking promotion or had actually prevented promotion.

Details on type of work and on the role of medical as opposed to surgical management were not investigated.

\section{Discussion}

Forty two per cent of young people with Crohn's disease lost time from school because of their Crohn's disease. Ill health was more widespread among young people with the disease. It is also likely that some people with Crohn's disease diagnosed after completion of their education lost time at school because of undiagnosed disease. This was not recorded in the survey. However, the time lost from school by these young people was significantly less than when illness affected a limited number of controls. Perhaps surprisingly, this illness did not significantly affect academic achievement, as measured by exam successes, although subjectively $14 \%$ of patients believed that disease had impaired their performance and $17 \%$ had at some time been unable to take an exam because of the disease. Such success was not due to partiality on the part of teachers or lecturers. Sixty seven per cent were unaware of their students' disease and amongst those who were, there was considerable indifference and even hostility.

Seventy nine per cent of patients with Crohn's disease were in active employment at the time of the study. Twice as many patients as controls had experienced periods of long term unemployment, although this did not reflect active dismissals. In the view of $37 \%$ of patients, employers should not know of their illness and $30 \%$ would actively conceal it. Although these views might simply reflect the experience of a 
TABLE III Employment experience of people with Crohn's disease

\begin{tabular}{lllll}
\hline & \multicolumn{4}{l}{ Controls $(\mathbf{n}=50)$} \\
\cline { 3 - 5 } & $\begin{array}{l}\text { Patients } \\
(\mathbf{n}=58)\end{array}$ & $\begin{array}{l}\text { Total } \\
(\mathbf{n}=50)\end{array}$ & $\begin{array}{l}\text { Buddy } \\
(\mathbf{n}=23)\end{array}$ & $\begin{array}{l}\text { Community } \\
(\mathbf{n}=27)\end{array}$ \\
\hline Currently employed & 46 & 45 & 18 & 27 \\
Has experienced long term employment & 29 & 12 & 5 & 7 \\
Has been dismissed from job & 4 & 4 & 2 & 2 \\
\hline
\end{tabular}

$\star_{z}=2 \cdot 0, \mathrm{p}<0.05$ Significantly more community than buddy controls were employed.

$\star \star z=2 \cdot 6, p<0 \cdot 01$ Significantly more patients than controls experienced long term employment.

TABLE IV Views of patients with Crohn's disease on employment

\begin{tabular}{ll}
\hline & $\begin{array}{l}\% \text { Patients } \\
(n=46)\end{array}$ \\
\hline $\begin{array}{l}\text { Employer unaware of diagnosis } \\
\text { Employers should not know diagnosis }\end{array}$ & 20 \\
Employee should conceal diagnosis & 37 \\
$\begin{array}{l}\text { Employer knows enough about Crohn's disease } \\
\text { Employer happy for patient to attend outpatients }\end{array}$ & 17 \\
$\quad$ during work time & 78 \\
$\begin{array}{l}\text { Disease prevented patient seeking promotion } \\
\text { Disease prevented promotion }\end{array}$ & 20 \\
$\begin{array}{l}\text { Disease resulted in a job different to that which the } \\
\text { patients would have otherwise expected }\end{array}$ & 17 \\
\hline
\end{tabular}

group of people well acquainted with the problems of long term employment they were held equally by those who had not personally experienced such difficulties. However, it is likely that patients exchange such experiences in clinics and through self help groups. They were not academically disadvantaged, and this, taken in conjunction with studies on employers, attitudes, shows practical discrimination against people with inflammatory bowel disease. ${ }^{7}$

Wyke et al interviewed 83 patients with Crohn's disease about employment problems they had experienced during the preceding six years and found that about $72 \%$ were employed. Changes in work as a result of ill health were common and in more than half were directly attributed to inflammatory bowel disease. About $19 \%$ of patients had not disclosed their diagnosis to their employer and several felt they had lost out on promotion, but when asked specifically, only seven felt they had been discriminated against. This is rather different from our interpretation of employment experience. There have been several other reports in which employment has been discussed. All have identified some degree of disability and unemployment among patients with Crohn's disease, but this is the first case-control study to consider these problems. Although the results might seem to support a complacent approach to education and employment for young people with Crohn's disease, academic success has largely been achieved despite the attitudes of lecturers and teachers. Similarly, active employment is against a background of chronic unemployment. Independent support for such an assessment comes from surveys among educational authorities and employers. $^{7}$

We would like to thank the Crohn's in Childhood Research Association for their support of this project through a research grant. Margaret Mayberry is the holder of an award from the British Digestive Foundation for work on the social needs of patients with gastrointestinal disease and the role of counselling.

1 Gazzard BG, Price HL, Libby GW, Dawson AM. The social toll of Crohn's Disease. BMF 1978; 2: 1117-9.

2 Drossman DA, Patrick DL, Mitchell CM, Zagami EA, Appelbaum MI. (1989) Health-related quality of life in inflammatory bowel disease. Functional status and patient worries and concerns. Dig Dis Sci 1989; 34: 1379-86.

3 Binder V, Hendriksen C, Kreiner S. Prognosis in Crohn's disease - based on results from a regional patient group from disease - based on results from a regional patient

the county of Copenhagen. Gut 1985; 26: 146-50.
4 Wyke RJ, Edwards FC, Allan RN. Employment problems and prospects for patients with inflammatory bowel disease. Gut 1988; 29: 1229-35.

5 Rose JD, Roberts GM, Williams G, Mayberry JF, Rhodes J. Cardiff Crohn's disease jubilee: the incidence over 50 years. Gut 1988; 29: 346-51.

6 Fleiss JL, ed. Statistical methods for rates and proportions. New York, John Wiley, 1981.

7 Probert CSJ, Jayanthi V, Mayberry JF. The attitude of employers to people with inflammatory bowel disease. Social Science and Medicine 1991. 